\title{
Thermodynamic Study for Arsenic Removal from Freshwater by Using Electrocoagulation Process
}

\author{
J. R. Parga ${ }^{*}$, J. L. Valenzuela ${ }^{2}$, G. T. Munive ${ }^{2}$, V. M. Vazquez ${ }^{2}$, M. Rodriguez ${ }^{1}$ \\ ${ }^{1}$ Department of Materials Science, Technological Institute of Saltillo, Saltillo Coahuila, Mexico \\ ${ }^{2}$ Department of Chemical Engineering and Metallurgy, University of Sonora, Hermosillo, Mexico \\ Email: ${ }^{*}$ irparga@its.mx
}

Received 20 August 2014; revised 16 September 2014; accepted 18 October 2014

Copyright (C) 2014 by authors and Scientific Research Publishing Inc.

This work is licensed under the Creative Commons Attribution International License (CC BY). http://creativecommons.org/licenses/by/4.0/

(c) (i) Open Access

\begin{abstract}
Insert Industrial treatment of mineral-processing and non-ferrous metal-smelting acid wastewater effluents is becoming an enormous worldwide problem. In Mexico, heavy metalscontaminated natural waters, including freshwater, surface water and ground water, are a significant problem as some of these compounds are known as toxic, mutagenic, and carcinogenic. A very promising electrochemical treatment technique that does not require chemical additions to remove arsenic is electrocoagulation (EC) with air injection. The proposed electrochemical process is efficient because used low cost iron electrodes and promising in industrial application. Theoretical the purpose of this research was to investigate the thermodynamic of arsenic adsorption on iron species using the Langmuir's Isotherm. Also, thermodynamic parameters such as $\Delta H^{\circ}, \Delta S^{\circ}$ and $\Delta G^{\circ}$ were calculated and the adsorption process was found to be exothermic and spontaneous. $X$-ray Diffraction and Scanning Electron Microscopy, were used to characterize the solid products formed during EC. The results of this study suggest that magnetite particles and amorphous iron oxyhydroxides are present in the examined EC products and this study indicate that arsenic can be successfully adsorbed on iron species by electrocoagulation process. Field pilot-scale study demonstrated the removal of $\mathrm{As}(\mathrm{III}) / \mathrm{As}(\mathrm{V})$ with an efficiency of more than $99 \%$ from both wastewater and wells.
\end{abstract}

\section{Keywords}

Coprecipitation, Electrocoagulation, Magnetite Particles

\footnotetext{
${ }^{*}$ Corresponding author.
}

How to cite this paper: Parga, J.R., Valenzuela, J.L., Munive, G.T., Vazquez, V.M. and Rodriguez, M. (2014) Thermodynamic Study for Arsenic Removal from Freshwater by Using Electrocoagulation Process. Advances in Chemical Engineering and Science, 4, 548-556. http://dx.doi.org/10.4236/aces.2014.44056 


\section{Introduction}

Arsenic contaminated natural waters, including surface water and ground water, are a significant problem as some of these compounds are known to be toxic, mutagenic, and carcinogenic. The deleterious health effects associated with ingestion of arsenic require that its concentrations should be kept below $10.0 \mathrm{ppb}$ in potable water supplies. The metals existing in wastewater are usually removed by precipitation. Arsenic is conventionally removed by chemical techniques such as treatment with lime, aluminum coagulation, iron coagulation, activated carbon and reverse osmosis [1]. These conventional processes generate a considerable quantity of secondary pollutants such as solid sludge, which also pose serious environmental problems. These drawbacks have forced various industries to search for effective alternative treatment technologies for arsenic removal, mainly electrochemical methods. The purpose of this research was to investigate the arsenic adsorption on iron species. A very promising electrochemical treatment technique that does not require addition of chemicals is electrocoagulation (EC) with air injection [2]. The EC process operates on the principle that the cations produced electrolytically from iron and/or aluminum anodes enhance the coagulation of contaminants from an aqueous medium. The sacrificial metal anodes are used to continuously produce polyvalent metal cations in the vicinity of the anode. These cations facilitate coagulation by neutralizing the negatively charged particles that are carried toward the anodes by electrophoretic motion. In the flowing EC techniques, the production of polyvalent cations from the oxidation of the sacrificial anodes ( $\mathrm{Fe}$ and/or $\mathrm{Al}$ ) and the production of electrolysis gases $\left(\mathrm{H}_{2}\right.$ and $\left.\mathrm{O}_{2}\right)$ are directly proportional to the amount of current applied (Faraday's law) [1]. The electrolysis gases enhance the flocculation of the coagulant materials.

EC is a complicated process involving many chemical and physical phenomena. It can be said that in an EC process the coagulant is produced "in situ" and this involves three successive stages:

1) Formation of coagulants by electrolytic oxidation of the "sacrificial electrode". Fe is dissolved from the anode generating corresponding metal ions, which almost immediately hydrolyze to ferric hydroxide and polymeric Iron; the generated $\mathrm{Fe}_{(\text {aq }}^{3+}$ ions will immediately undergo further spontaneous reactions to produce corresponding hydroxides and/or polyhydroxides. Ferric ions generated by electrochemical oxidation of iron electrode may form monomeric ions, $\mathrm{Fe}(\mathrm{OH})_{3}$ and polymeric hydroxy complexes, namely: $\mathrm{Fe}\left(\mathrm{H}_{2} \mathrm{O}\right)_{6}^{3+}, \quad \mathrm{Fe}\left(\mathrm{H}_{2} \mathrm{O}\right)_{5}(\mathrm{OH})_{2}^{+}, \quad \mathrm{Fe}\left(\mathrm{H}_{2} \mathrm{O}\right)_{4}(\mathrm{OH})^{2+}, \quad \mathrm{Fe}_{2}\left(\mathrm{H}_{2} \mathrm{O}\right)_{8}(\mathrm{OH})_{2}^{4+}$ and $\mathrm{Fe}_{2}\left(\mathrm{H}_{2} \mathrm{O}\right)_{6}(\mathrm{OH})_{4}^{4+}$ depending on the $\mathrm{pH}$ of the aqueous medium. These hydroxides/polyhydroxides/polyhydroxymetallic compounds have strong affinity for dispersed particles as well as counter ions to cause coagulation. The gas evolved at the cathode may impinge on and cause flotation of the coagulated materials.

2) Destabilization of the contaminants, particulate suspension, and breaking of emulsions. Contaminants present in the wastewater stream are treated either by chemical reactions and precipitation or physical and chemical attachment to coagulant materials.

3) Aggregation of the destabilized phases to form flocs. Polymeric hydroxides are excellent coagulating agent

EC has been employed for removing heavy metals such as $\mathrm{Pb}, \mathrm{Cd}, \mathrm{Cr}$ and $\mathrm{As}$, metals such as $\mathrm{Mn}, \mathrm{Cu}, \mathrm{Zn}, \mathrm{Ni}$, $\mathrm{Al}, \mathrm{Fe}, \mathrm{Co}, \mathrm{Sn}, \mathrm{Mg}$, Se, Mo, Ca, Pt among others, anions such as $\mathrm{CN}, \mathrm{PO}_{4}, \mathrm{SO}_{4}, \mathrm{NO}_{3}$, $\mathrm{F}$ and $\mathrm{Cl}$, non metals such as P, organic compounds such as TPH, TBX, MTBE, COD, BOD, suspended solids, clay minerals, organic dyes, oil and greases from a variety of industrial effluents. Some of the factors that influence EC performance are: type of electrolytes, electrodes material, applied power, acidity and final $\mathrm{pH}$. A schematic representation of the EC process is shown in Figure 1.

The chemical reactions that have been proposed to describe EC mechanisms for the production of $\mathrm{H}_{2(\mathrm{~g})}$, $\mathrm{OH}_{(\mathrm{aq})}^{-}$and $\mathrm{H}_{(\mathrm{aq})}^{+}[3][4]$ at different $\mathrm{pH}$ values are:

For $\mathrm{pH}<4$

Anode:

$$
\begin{aligned}
& \mathrm{Fe} \rightarrow \mathrm{Fe}^{+2}+2 \mathrm{e} \\
& \mathrm{Fe} \rightarrow \mathrm{Fe}^{+3}+3 \mathrm{e}
\end{aligned}
$$

Cathode:

$$
2 \mathrm{H}^{+}+2 \mathrm{e}^{-} \rightarrow \mathrm{H}_{2(\mathrm{~g})} \uparrow
$$




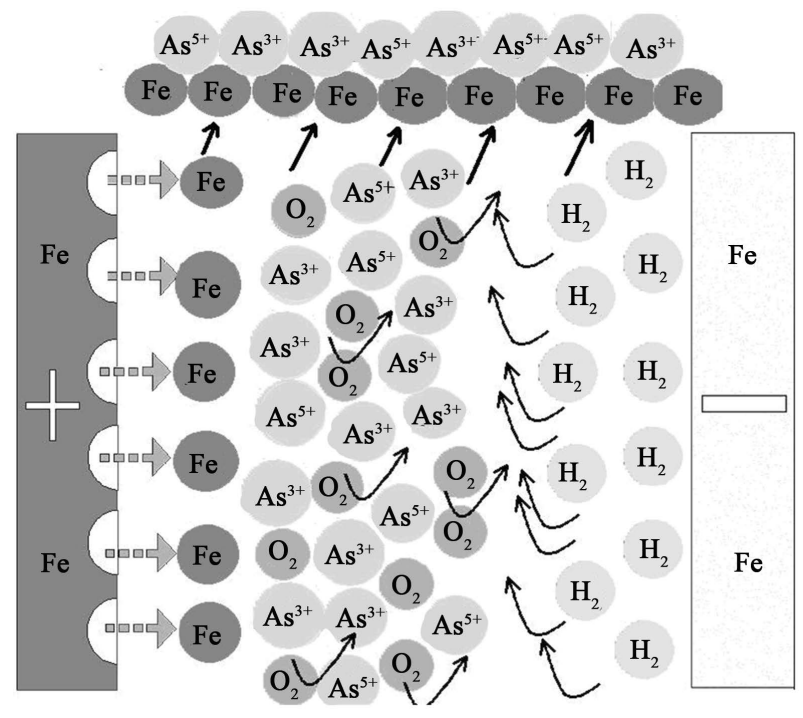

Figure 1. Conceptual illustration of the EC mechanism.

For $4<\mathbf{p H}<7$ :

Anode: reactions (1) and (2)

Comments:

In fact iron also undergoes hydrolysis

$$
\begin{gathered}
\mathrm{Fe}+6 \mathrm{H}_{2} \mathrm{O} \rightarrow \mathrm{Fe}\left(\mathrm{H}_{2} \mathrm{O}\right)_{4}(\mathrm{OH})_{2} \\
\mathrm{Fe}+6 \mathrm{H}_{2} \mathrm{O} \rightarrow \mathrm{Fe}\left(\mathrm{H}_{2} \mathrm{O}\right)_{3}(\mathrm{OH})_{3(\text { aq })}+3 \mathrm{H}^{+1}+3 \mathrm{e}^{-1}
\end{gathered}
$$

Fe(III) hydroxide begins to precipitate floc with yellowish color.

$$
\mathrm{Fe}\left(\mathrm{H}_{2} \mathrm{O}\right)_{3}(\mathrm{OH})_{3(\mathrm{aq})} \rightarrow \mathrm{Fe}\left(\mathrm{H}_{2} \mathrm{O}\right)_{3}(\mathrm{OH})_{3(\mathrm{~s})}
$$

"Rust" may also be formed [4].

$$
2 \mathrm{Fe}\left(\mathrm{H}_{2} \mathrm{O}\right)_{3}(\mathrm{OH})_{3} \leftrightarrow \mathrm{Fe}_{2} \mathrm{O}_{3}\left(\mathrm{H}_{2} \mathrm{O}\right)_{6}
$$

Cathode: More hydrogen evolution takes place (Equation (3)); but $\left[\mathrm{H}^{+}\right]$now comes from weak acids and iron hydrolysis.

For $6<\mathbf{p H}<\mathbf{9}$ :

Anode: reactions (1) and (2)

Comments:

Precipitation of Fe(III) hydroxide (7) continues, and Fe(II) hydroxide precipitation also occurs presenting a dark green floc.

$$
\mathrm{Fe}\left(\mathrm{H}_{2} \mathrm{O}\right)_{4}(\mathrm{OH})_{2(\mathrm{aq})} \rightarrow \mathrm{Fe}\left(\mathrm{H}_{2} \mathrm{O}\right)_{4}(\mathrm{OH})_{2(\mathrm{~s})}
$$

The $\mathrm{pH}$ for minimum solubility of $\mathrm{Fe}(\mathrm{OH})_{n}$ is in the range of 7 - 8. EC floc is formed due to the polymerization of iron oxyhydroxides [5].

Formation of rust (dehydrated hydroxides) occurs as shown in the following:

$$
\begin{gathered}
2 \mathrm{Fe}(\mathrm{OH})_{3} \leftrightarrow \mathrm{Fe}_{2} \mathrm{O}_{3}+3 \mathrm{H}_{2} \mathrm{O} \text { (hematite, maghemite) } \\
\mathrm{Fe}(\mathrm{OH})_{2} \leftrightarrow \mathrm{FeO}+\mathrm{H}_{2} \mathrm{O} \\
2 \mathrm{Fe}(\mathrm{OH})_{3}+\mathrm{Fe}(\mathrm{OH})_{2} \leftrightarrow \mathrm{Fe}_{3} \mathrm{O}_{4}+4 \mathrm{H}_{2} \mathrm{O} \text { (magnetite) } \\
\mathrm{Fe}(\mathrm{OH})_{3} \leftrightarrow \mathrm{FeO}(\mathrm{OH})+\mathrm{H}_{2} \mathrm{O} \text { (goethite, lepidocrocite) }
\end{gathered}
$$


Hematite, maghemite, rust, magnetite, lepidocrocite and goethite have been identified as EC by-products [6].

Cathode: More hydrogen evolution takes place (Equation (3)); but $\left[\mathrm{H}^{+}\right]$now comes from weak acids and iron hydrolysis.

Overall reactions are:

$$
\begin{gathered}
\mathrm{Fe}+6 \mathrm{H}_{2} \mathrm{O} \rightarrow \mathrm{Fe}\left(\mathrm{H}_{2} \mathrm{O}\right)_{4}(\mathrm{OH})_{2(\mathrm{~s})}+\mathrm{H}_{2(\mathrm{~g})} \uparrow \\
\mathrm{Fe}+6 \mathrm{H}_{2} \mathrm{O} \rightarrow \mathrm{Fe}\left(\mathrm{H}_{2} \mathrm{O}\right)_{3}(\mathrm{OH})_{3(\mathrm{~s})}+\frac{3}{2} \mathrm{H}_{2(\mathrm{~g})} \uparrow
\end{gathered}
$$

Conditions throughout the cell are not constant; concentrations, species and $\mathrm{pH}$ are changing. This may be illustrated with an iron Pourbaix diagram.

\section{Materials and Methods}

The adsorption experiments were performed in a $400 \mathrm{ml}$ glass beaker equipped with two carbon steel electrodes $(6 \mathrm{~cm} \times 3 \mathrm{~cm})$ located $5 \mathrm{~mm}$ apart. There was used a source of current and voltage (universal AC/DC adaptor). The $\mathrm{pH}$ was measured with an electrode/pH meter-VWR scientific 8005. Arsenic adsorption onto iron species was investigated with electrolytes prepared with sodium arsenate $\mathrm{Na}_{2} \mathrm{HAsO}_{4}$, (analytical reagent with a purity of 97\% supplied by Chemical Products, Monterrey) and deionized water with conductivity of $0.95 \mu \mathrm{S} \mathrm{cm}{ }^{-1}$ (Aldrich Chemical Co. 99.5\%). The solutions and solids were then separated by filtration through cellulose filter paper. The sludge from the EC was dried either in an oven or under vacuum at room temperature. The experimental set-up is presented in Figure 2. The current and voltage during the EC process were measured and recorded, using Cen-Tech multimeters. The $\mathrm{pH}$ values of the solution before and after EC were measured with a VWR scientific $8005 \mathrm{pH}$ meter.

In Table 1, the initial conditions of arsenic for the range of concentrations listed are presented. The Langmuir isotherm model was used to analyze adsorption data.

The amount of arsenic adsorbed onto iron species at equilibrium $N(\mathrm{mg} / \mathrm{g})$ was calculated by using the following relationship [7]:

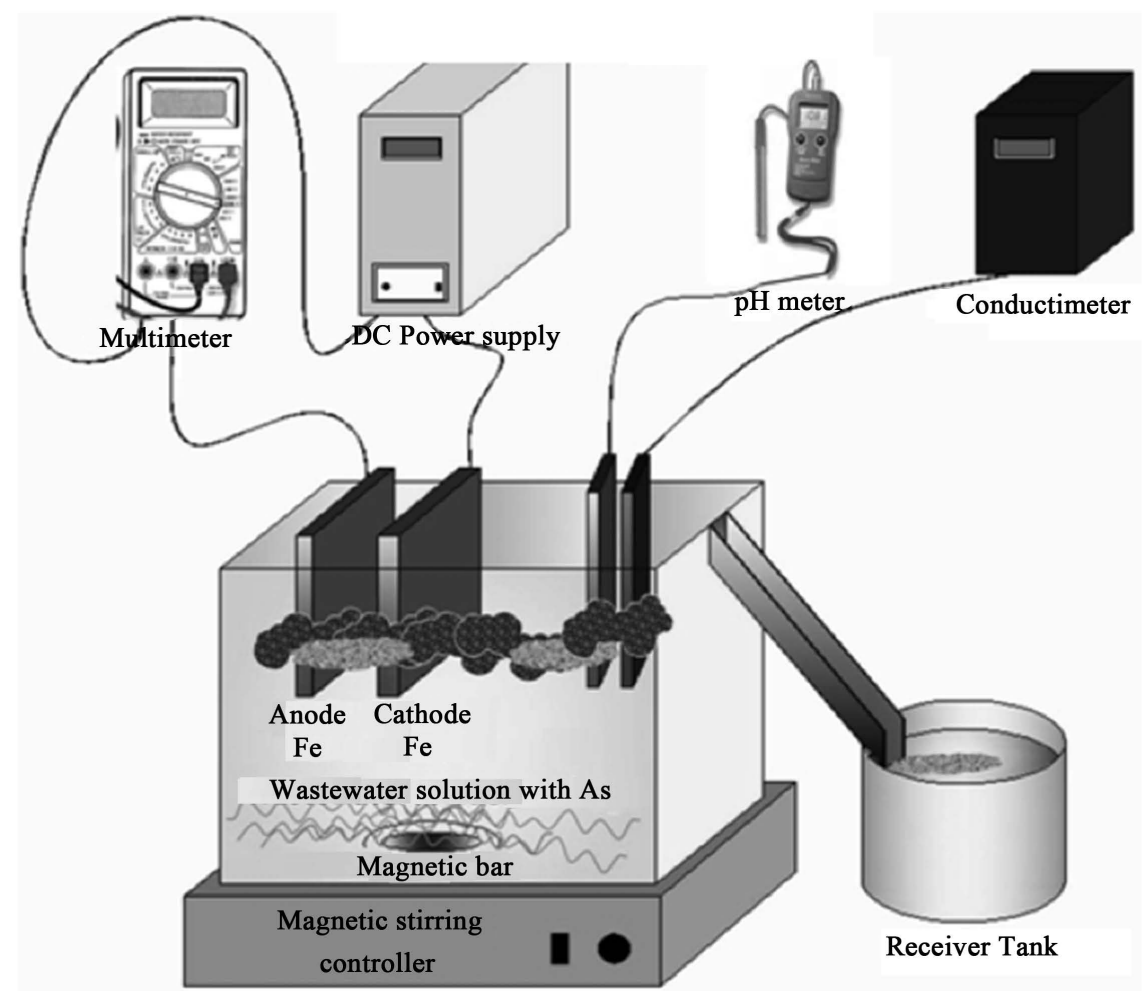

Figure 2. Experimental set-up for arsenic removal two-electrode electrocoagulation cell. 
Table 1. Conditions for arsenic adsorption experiments.

\begin{tabular}{ccccccc}
\hline Samples & Concentration $(\mathrm{mg} / \mathrm{L})$ & Temperature $\left({ }^{\circ} \mathrm{C}\right)$ & $\mathrm{pH}$ & Current $(\mathrm{A})$ & Cell Potential $(\mathrm{V})$ & Time $(\mathrm{min})$ \\
\hline 1 & 1 & 20 & 2.86 & 0.49 & 8.5 & 5 \\
2 & 2 & 20 & 3.02 & 0.52 & 12 & 5 \\
3 & 5 & 20 & 2.90 & 0.44 & 10 & 5 \\
4 & 7 & 20 & 3.05 & 0.41 & 12.8 & 5 \\
5 & 13 & 20 & 2.90 & 0.48 & 10.7 & 5 \\
6 & 20 & 20 & 3.02 & 0.50 & 10.25 & 5 \\
7 & 30 & 20 & 4.14 & 0.75 & 6.68 & 5 \\
\hline
\end{tabular}

$$
N=V\left[\mathrm{C}_{0}-\mathrm{C}_{\mathrm{e}}\right] / \mathrm{W}
$$

which, $\mathrm{C}_{0}$ and $\mathrm{C}_{\mathrm{e}}(\mathrm{mg} / \mathrm{L})$ are the liquid phase concentrations of arsenic initially and at equilibrium, respectively, $V$ the volume of the solution (L) and $W$ is the mass of adsorbent used (g) (in this case the Fe dissolved from EC). The mass of metal dissolved (or other species discharged) depends on the quantity of charge (electrons) supplied to the electrocoagulation cell during the holding time that happens across the electrolytic solution and the time of residence of the water in the electrocoagulation cell. A simple relation between the current density and the quantity of substance dissolved (g of $M$ per $\mathrm{cm}^{2}$ ) stems from Faraday's law [7]:

$$
W=\frac{D \cdot t \cdot M}{n \cdot F}
$$

where $W$ is the mass of the electrode dissolved $\left(\mathrm{g} / \mathrm{cm}^{-2}\right), D$ is the density of current (A per $\mathrm{cm}^{-2}$ ), $t$ is the time (seconds), $M$ is the relative molar mass of the electrode, $n$ the electrons number in the electrode reaction, and $F$ is Faraday’s constant (96,500 coulombs). Then, arsenic moles numbers adsorbed onto iron species are calculate by Equation (15).

In Table 2 arsenic moles number adsorbed onto iron species are presented. High adsorption was showed while the concentration increases.

Then, the Langmuir isotherm was employed to describe the adsorption equilibrium in the system:

$$
N=\left(\frac{N_{\text {Max }} K_{L} \mathrm{C}_{\mathrm{e}}}{1+K_{L} \mathrm{C}_{\mathrm{e}}}\right)
$$

where $N$ is the amount of arsenic adsorbed onto iron species in equilibrium $(\mathrm{mg} / \mathrm{g}), N_{\max }$ is the maximum adsorption capacity corresponding to complete monolayer coverage on the surface (mg/g), $\mathrm{C}_{\mathrm{e}}$ is the equilibrium concentrations of metals ions in the solution at equilibrium $(\mathrm{mg} / \mathrm{L})$ and $K_{L}$ is the Langmuir constant (L/mg). Equation (7) can be rearranged to a linear form as follows [8]:

$$
\frac{C}{N}=\frac{1}{N_{\text {Max }} K_{L}}+\frac{\mathrm{C}_{\mathrm{e}}}{N_{\text {Max }}}
$$

\section{Results and Discussion}

Following the model of the Langmuir's isotherm (see Figure 2) shows the arsenic adsorption capacity on iron species. The constants can be evaluated from the intercepts and the slopes of the linear plots of $\mathrm{C}_{\mathrm{e}} / N$ versus $\mathrm{C}_{\mathrm{e}}$. Table 2, shows the results of the linear regression. The value of $N_{\max }$ indicates the maximum adsorption capacity corresponding to complete monolayer coverage on the iron surface. The value of $K_{L}$ is the constant of adsorption of Langmuir.

The thermodynamic parameters [such as change in standard free energy $\left(\Delta G^{\circ}\right)$, enthalpy $\left(\Delta H^{\circ}\right)$ and entropy $\left(\Delta S^{\circ}\right)$ were determined [5] by using the following equations:

$$
\begin{gathered}
\ln b=-\frac{\Delta G^{\circ}}{R T} \\
\ln (b)=b_{0}-\left(\frac{\Delta H^{\circ}}{R T}\right)
\end{gathered}
$$


Table 2. Arsenic moles adsorbed on iron species (N).

\begin{tabular}{ccccc}
\hline Sample & $\mathrm{C}_{0 \mathrm{As}}(\mathrm{mmol} / \mathrm{L})$ & $\mathrm{C}_{\mathrm{eAs}}(\mathrm{mmol} / \mathrm{L})$ & $\mathrm{W}(\mathrm{g})$ & $\mathrm{N}(\mathrm{mmol} / \mathrm{g})$ \\
\hline 1 & 0.013347 & 0.0002 & 0.028435 & 0.161827 \\
2 & 0.026695 & 0.0006 & 0.033658 & 0.270655 \\
3 & 0.066737 & 0.0009 & 0.025534 & 0.901994 \\
4 & 0.093432 & 0.0020 & 0.023793 & 1.344981 \\
5 & 0.173518 & 0.0049 & 0.027855 & 2.118223 \\
6 & 0.266951 & 0.0126 & 0.029016 & 3.067147 \\
7 & 0.400427 & 0.0168 & 0.043523 & 3.084857 \\
\hline
\end{tabular}

$$
\Delta G_{\mathrm{ads}}^{\circ}=\Delta H_{\mathrm{ads}}^{\circ}-T \Delta S_{\mathrm{ads}}^{\circ}
$$

In which $R$ is the gas constant, $T\left({ }^{\circ} \mathrm{K}\right)$ the absolute temperature, $b$ is the Langmuir's constant which is related to the energy of adsorption, and $b_{0}$ is a constant. Table 3; show the negative value of $\Delta G^{\circ}$ obtained, indicated that the arsenic adsorption on iron species by EC is a spontaneous process. The negative value of $\Delta H^{\circ}$ represents an exothermic process and suggests a fisiadsorption behavior according with the liberated heat between -20 and $-40 \mathrm{KJ} / \mathrm{mol}$. The negative value of $\Delta S^{\circ}$ suggests that a significant change does not happen in the internal structure of the adsorbent during the adsorption of As.

\section{Product Characterization}

In this study, chemical analysis, powder X-ray diffraction (XRD), and scanning electron microscopy (SEM) were used to characterize the solid products generated in the EC cell, operated with carbon-steel electrodes. Figure 3 shows the diffractogram for an arsenic sample obtained from a solution at pH 7, containing 2 ppm arsenic. The species identified were magnetite, goethite, lepidocrocite, iron arsenate and iron hydroxide oxide in crystalline form.

Figure 4, shows, respectively, the SEM and EDAX images of As contaminated iron oxide/oxyhydroxide particles. These displays show that the surfaces of these iron oxide/oxyhydroxide particles were coated with a layer of As species.

Also, the results of this study suggest that EC produces magnetic particles of magnetite and amorphous iron oxyhydroxide species that serve to remove As(III)/As(V) species. In order to prove this, FTIR spectra for solids collected from EC trials with various starting $\mathrm{pH}$ value of ca. 7.0. The positions of the important absorption bands for the various iron containing phases are summarized in Table 1 [9]-[15]. This table is modeled after the work by Nauer et al. [9] that tabulated the peak positions of goethite $(\delta$-FeOOH), akaganéite $(\delta$-FeOOH), lepidocrocite $(\delta$-FeOOH$)$, feroxyhite $(\delta$-FeOOH$)$, and bernalite $\left(\mathrm{Fe}(\mathrm{OH})_{3}\right)$. These authors also used the following assignments for IR absorbances:

1) 3600 to са. $3000 \mathrm{~cm}^{-1}$ : OH stretching vibration, $v(\mathrm{OH})$.

2) 1200 to $600 \mathrm{~cm}^{-1}: \mathrm{Fe}-\mathrm{O}-\mathrm{H}$ bending vibrations and Fe-O stretching vibrations.

3) 600 to $200 \mathrm{~cm}^{-1}$ : absorptions caused by the overlapping of lattice vibrations with molecular frequencies (Fe-O stretching vibrations can also absorb down to ca. $350 \mathrm{~cm}^{-1}$ ).

After examining the spectra in that work, the current authors added the indications of shoulders on the $v(\mathrm{OH})$ stretching vibrations for $\delta$-FeOOH, $\delta$-FeOOH, and $\delta$-FeOOH. For $\delta$-FeOOH, trimodality of the $v(\mathrm{OH})$ stretching vibrations has also been indicated by adding the peaks at both 3450 and $2900 \mathrm{~cm}^{-1}$. Another extensive study by Weckler and Lutz [12] found spectra for $\delta$-FeOOH, $\delta$-FeOOH, $\delta$-FeOOH, and $\delta$-FeOOH that closely resemble those summarized in Table 4. However, two additional features were added for goethite. The earlier work of Misawa et al. [13] also confirm the results discussed above for $\delta$-FeOOH and also assigned a peak at $470 \mathrm{~cm}^{-1}$ and shoulders at 668 and $442 \mathrm{~cm}^{-1}$ to magnetite $\left(\mathrm{Fe}_{3} \mathrm{O}_{4}\right)$. However, Musić [14] and Nasrazadani [10] observed peaks at ca. 575 and $385 \mathrm{~cm}^{-1}$ for magnetite and Nyquist and Kagel [15] observed peaks at 725 and $575 \mathrm{~cm}^{-1}$ for magnetite. The study by Musić [15] was also used as a reference for additional peaks for $\mathrm{Fe}(\mathrm{OH})_{3}$, while Nasrazadani also assigned peaks at 630 and $430 \mathrm{~cm}^{-1}$ to maghemite $\left(\delta-\mathrm{Fe}_{2} \mathrm{O}_{3}\right)$. 


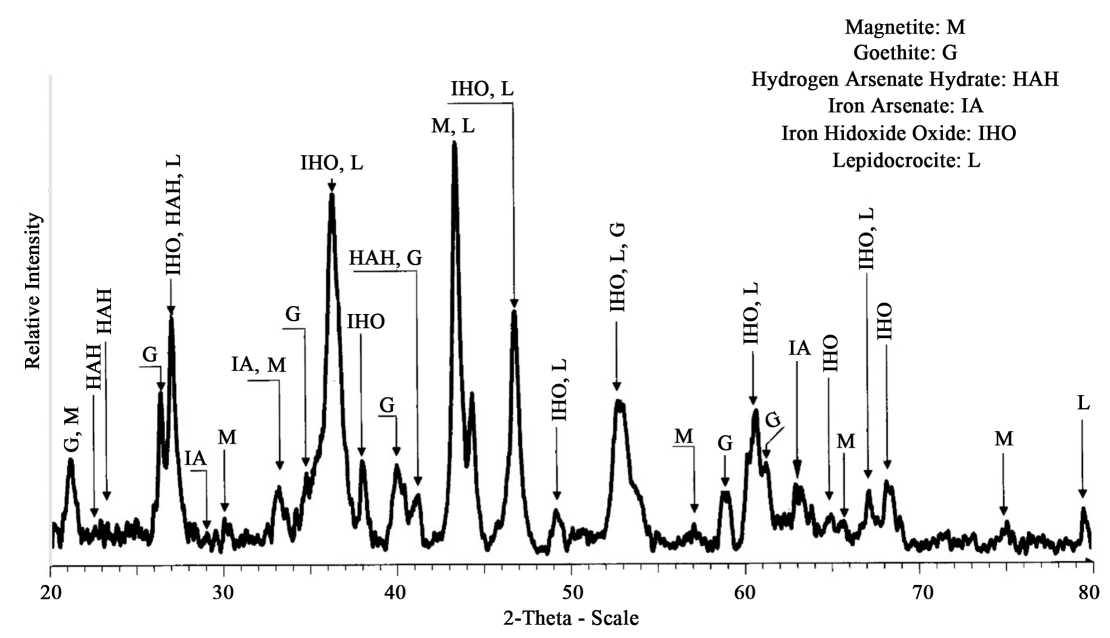

Figure 3. XRD diffractogram for the iron impregnated with arsenic.

Table 3. Linear regression results for arsenic adsorption onto iron species.

\begin{tabular}{cc}
\hline Parameter & Results \\
\hline $\mathrm{R}^{2}$ & 0.9665 \\
$\mathrm{~N}_{\max }\left(\mathrm{mmol}_{\mathrm{As}} / \mathrm{gFe}\right)$ & 4.242281 \\
$\mathrm{~K}_{\mathrm{L}}(\mathrm{L} / \mathrm{mmol})$ & 181.30 \\
\hline
\end{tabular}

Table 4. Infrared frequencies of the Fe-oxyhydroxides $\left(\mathrm{cm}^{-1}\right)$ [9]-[15].

\begin{tabular}{|c|c|c|c|c|c|c|c|c|c|c|c|c|c|c|c|}
\hline & & \multirow{2}{*}{$\begin{array}{l}\text { Goethite } \\
\alpha \text {-FeOOH }\end{array}$} & \multicolumn{2}{|c|}{ Akaganéite } & \multicolumn{2}{|c|}{ Lepidocrocite } & \multicolumn{2}{|r|}{ Feroxyhite } & \multicolumn{2}{|r|}{ Bernalite } & \multicolumn{2}{|c|}{ Hematite } & \multirow{2}{*}{$\begin{array}{r}\text { Maghemite } \\
\gamma-\mathrm{Fe}_{2} \mathrm{O}_{3}\end{array}$} & \multicolumn{2}{|c|}{ Magnetite } \\
\hline & & & & $\beta$-FeOOH & & $\gamma$-FeOOH & & $\delta$-FeOOH & & $\mathrm{Fe}(\mathrm{OH})_{3}$ & & $\alpha-\mathrm{Fe}_{2} \mathrm{O}_{3}$ & & & $\mathrm{Fe}_{3} \mathrm{O}_{4}$ \\
\hline \multirow[t]{3}{*}{ 1) } & sh & $3500^{*}$ & ss & 3480 & & & $\mathrm{~s}$ & $3450^{*}$ & & & & & & & \\
\hline & s & 3155 & sh & $3000^{*}$ & $\mathrm{~s}$ & 3100 & $\mathrm{~s}$ & 3150 & $\mathrm{~m}$ & $3500-2500$ & & & & & \\
\hline & & $1385^{\mathrm{d}}$ & & & sh & $2800^{*}$ & $\mathrm{~s}$ & $2900^{*}$ & & $1507^{c}$ & & & & & \\
\hline \multirow[t]{6}{*}{ 2) } & $\begin{array}{l}\mathrm{w} \\
\mathrm{w}\end{array}$ & $\begin{array}{l}1125^{\mathrm{a}} \\
1081^{\mathrm{a}}\end{array}$ & & & $\begin{array}{c}\mathrm{m} \\
\mathrm{s}\end{array}$ & $\begin{array}{l}1155 \\
1160^{f}\end{array}$ & $\mathrm{~m}$ & 1130 & vw & $1044^{c}$ & $\mathrm{w}$ & $1010^{f}$ & & & \\
\hline & $\mathrm{w}$ & $1020^{\mathrm{f}}$ & & & $\begin{array}{l}\mathrm{m} \\
\mathrm{s}\end{array}$ & $\begin{array}{l}1020 \\
1020^{\mathrm{f}}\end{array}$ & $\mathrm{m}$ & 915 & & & & & & & \\
\hline & $\mathrm{s}$ & 890 & sh & 875 & & & & & & & $\mathrm{w}$ & $885^{\mathrm{f}}$ & & & \\
\hline & $\mathrm{s}$ & 790 & $\mathrm{w}$ & 800 & $\mathrm{~s}$ & 740 & $\mathrm{~s}$ & 795 & & & & & & & \\
\hline & & & $\mathrm{s}$ & 700 & & & & & & & & $725^{\mathrm{e}}$ & $785^{\mathrm{d}}$ & & $725^{\mathrm{e}}$ \\
\hline & $\mathrm{s}$ & 640 & $\mathrm{w}$ & 620 & & & & & & & & $\begin{array}{l}590^{\mathrm{e}} \\
535^{\mathrm{e}}\end{array}$ & $630^{\mathrm{d}}$ & sh & $668^{\mathrm{b}}$ \\
\hline 3) & $\mathrm{sh}$ & 455 & & & ss & 480 & ss & 460 & & $\begin{array}{l}566^{c} \\
448^{c}\end{array}$ & & $568^{c}$ & $550^{\mathrm{d}}$ & s & $\begin{array}{c}570^{\mathrm{c}, \mathrm{d}} \\
470^{\mathrm{b}}\end{array}$ \\
\hline & ss & 400 & ss & 425 & ss & 360 & & & & & & & & sh & $442^{\mathrm{b}}$ \\
\hline & $\mathrm{s}$ & 270 & & & ss & 270 & SS & 335 & & & & & & & $385^{\mathrm{c,d}}$ \\
\hline
\end{tabular}

Peak notes: very strong (ss), strong (s), medium (m), weak (w), very weak (vw), shoulder (sh), broad (b).

\section{Conclusion}

The results of this study indicate that arsenic is readily adsorbed onto iron species generated by electrocoagulation. It was found that $99 \%$ of the arsenic in a batch cell is removed in the lab-scale EC reactor within 60 seconds or less for most experiments, and with a current efficiency of $100 \%$. Correlation of the adsorption behavior with the Langmuir isotherm revealed an adsorption capacity of $4.24 \mathrm{mmol}$ As/g of Fe absorbent. The negative values of $\Delta G^{\circ}$ obtained indicate that the arsenic adsorption onto iron species generated by EC is a spontaneous process. The negative values of $\Delta H^{\circ}$ represent an exothermic process. 

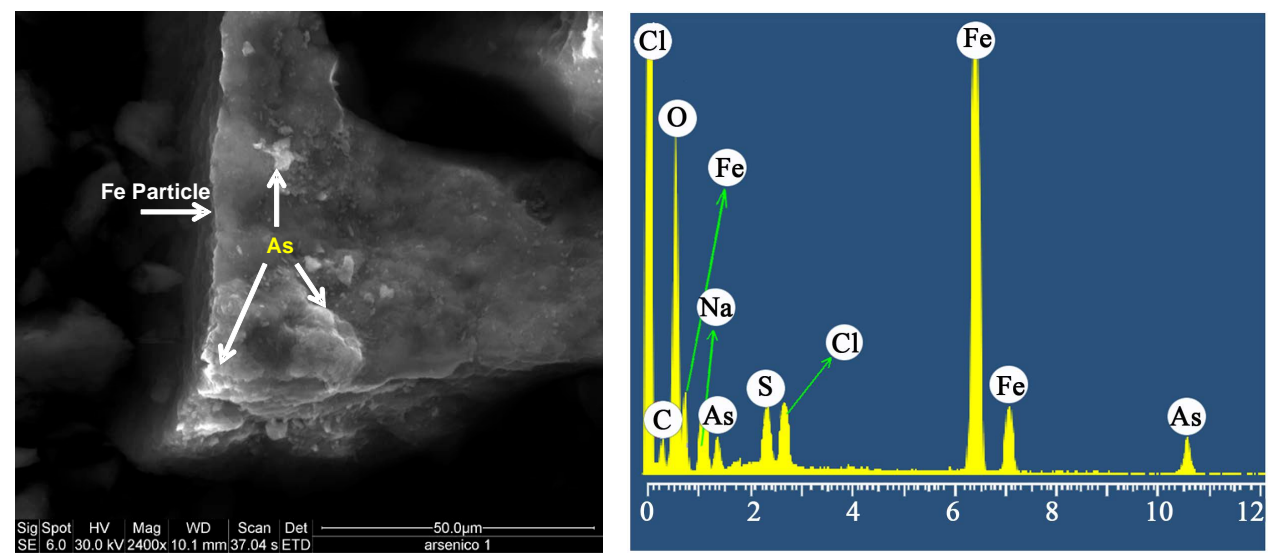

Figure 4. SEM and EDAX images for by-products generated from the arsenic contaminated water samples.

\section{Acknowledgements}

The authors acknowledge the financial support of this research provided by CONACYT, TecNM (ITS), USAID and GOBIERNO DE COAHUILA for his contribution in the presentation of these manuscript.

\section{References}

[1] Gomes, J.A., Cocke, D.L., Daida, P., Kesmez, M., Weir, M., Moreno, H., Parga, J.R., Irwin, G., McWhinney, H., Gradyand, T. and Peterson, E. (2007) Arsenic Removal by Electrocoagulation Using Combined Al-Fe Electrode System and Characterization of Products. Journal of Hazardous Material, B139, 220-231.

http://dx.doi.org/10.1016/j.jhazmat.2005.11.108

[2] Parga, J.R., Cocke, D.L., Valenzuela, J.L., Gomes, J.A., Kesmez, M., Irwin, G., Moreno, H. and Weir, M. (2005) Arsenic Removal via Electrocoagulation from Heavy Metal Contaminated Groundwater in La Comarca Lagunera Mexico. Journal of Hazardous Materials, B124, 247-254. http://dx.doi.org/10.1016/j.jhazmat.2005.05.017

[3] Mohora, E., Roncevic, S., Agbaba, J., Tubic, A. and Mitic, M. (2014) Removal of Arsenic from Groundwater Rich in Natural Organic Matter (NOM) by Continuous Electrocoagulation/Flocculation (ECF), Separation and Purification Technology, Available online 16 September 2014.

[4] Moreno, H., Cocke, D.L., Gomes, J.A., Morkovsky, P., Parga, J.R., Peterson, E. and Garcia, C. (2007) Electrochemical Generation of Green Rust with Electrocoagulation. ECS Transactions, 3, 67-76.

[5] Parga, J.R., Vazquez, V. and Casillas, H. (2009) Cyanide Detoxification of Mining Wastewaters with TiO ${ }_{2} \mathrm{Nanopar-}^{-}$ ticles and Its Recovery by Electrocoagulation. Chemical Engineering and Technology, 32, 1901-1908. http://dx.doi.org/10.1002/ceat.200900177

[6] Roy, P., Mondale, N.K. and Das, K. (2014) Modeling of the Adsorptive removal of Arsenic: A Statistical Approach. Journal of Environmental Chemical Engineering, 2, 585-597.

[7] Mólgoraa, C.C., Domíngueza, A.M., Avilab, E.M., Droguic, P. and Buelnad, G. (2013) Removal of Arsenic from Drinkingwater: A Comparative Study between Electrocoagulation-Micrifiltration and Chemical Coagulation-Microfiltration Process. Separation and Purification Technology, 118, 645-651. http://dx.doi.org/10.1016/j.seppur.2013.08.011

[8] Zhang, P., Tong, M., Young, S. and Liao, P. (2014) Transformation and Removal of Arsenic in Groundwater by Sequential Anodic Oxidation and Electrocoagulation. Journal of Contaminant Hydrology, 164, 299-307. http://dx.doi.org/10.1016/j.jconhyd.2014.06.009

[9] Nauer, G., Stretcha, P., Brinda-Konopik, N. and Liptay, G. (1985) Spectroscopic and Thermoanalytical Characterization of Standard Substances for the Identification of Reaction Products on Iron Electrodes. Journal of Thermal Analysis, 30, 813-830. http://dx.doi.org/10.1007/BF01913309

[10] Nasrazadan, S. and Raman, A. (1993) The Application of Infrared Spectroscopy to the Study of Rust Systems-II. Study of Cation Deficiency in Magnetite $\left(\mathrm{Fe}_{3} \mathrm{O}_{4}\right)$ Produced during Its Transformation to Maghemite $\left(\gamma-\mathrm{Fe}_{2} \mathrm{O}_{3}\right)$ and Hematite $\left(\alpha-\mathrm{Fe}_{2} \mathrm{O}_{3}\right)$. Corrosion Science, 34, 1355-1365. http://dx.doi.org/10.1016/0010-938X(93)90092-U

[11] Parfitt, R.L. and Smart, R. (1978) The Mechanism of Sulfate Adsorption on Iron Oxides ${ }^{1}$. Soil Science Society of American Journal, 42, 48. http://dx.doi.org/10.2136/sssaj1978.03615995004200010011x

[12] Weckler, B. and Lutz, H.D. (1998) Lattice Vibration Spectra. Part XCV. Infrared Spectroscopic Studies on the Iron 
Oxide Hydroxides Goethite $(\alpha)$, Akaganéite $(\beta)$, Lepidocrocite $(\gamma)$ and Feroxyhite $(\delta)$. European Journal of Solid State and Inorganic Chemistry, 35, 531-544. http://dx.doi.org/10.1016/S0992-4361(99)80017-4

[13] Misawa, T., Kyuno, T., Suëtaka, W. and Shimodaira, S. (1971) The Mechanism of Atmospheric Rusting and the Effect of $\mathrm{Cu}$ and $\mathrm{P}$ on the Rust Formation of Low Alloy Steels. Corrosion Science, 11, 35-48. http://dx.doi.org/10.1016/S0010-938X(71)80072-0

[14] Musić, S., Gotić, M. and Popović, S. (1993) X-Ray Diffraction and Fourier Transform-Infrared Analysis of the Rust Formed by Corrosion of Steel in Aqueous Solutions. Journal of Materials Science, 28, 5744-5752. http://dx.doi.org/10.1007/BF00365176

[15] Nyquist, R.A. and Kagel, R.O. (1971) Infrared Spectra of Inorganic Compounds (3800-450 $\mathrm{cm}^{-1}$ ), 218. Academic Press, New York and London. 
Scientific Research Publishing (SCIRP) is one of the largest Open Access journal publishers. It is currently publishing more than 200 open access, online, peer-reviewed journals covering a wide range of academic disciplines. SCIRP serves the worldwide academic communities and contributes to the progress and application of science with its publication.

Other selected journals from SCIRP are listed as below. Submit your manuscript to us via either submit@scirp.org or Online Submission Portal.
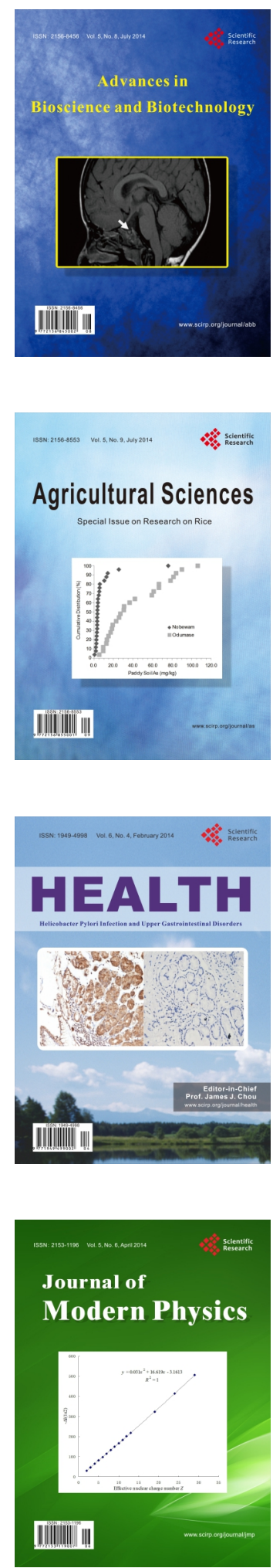
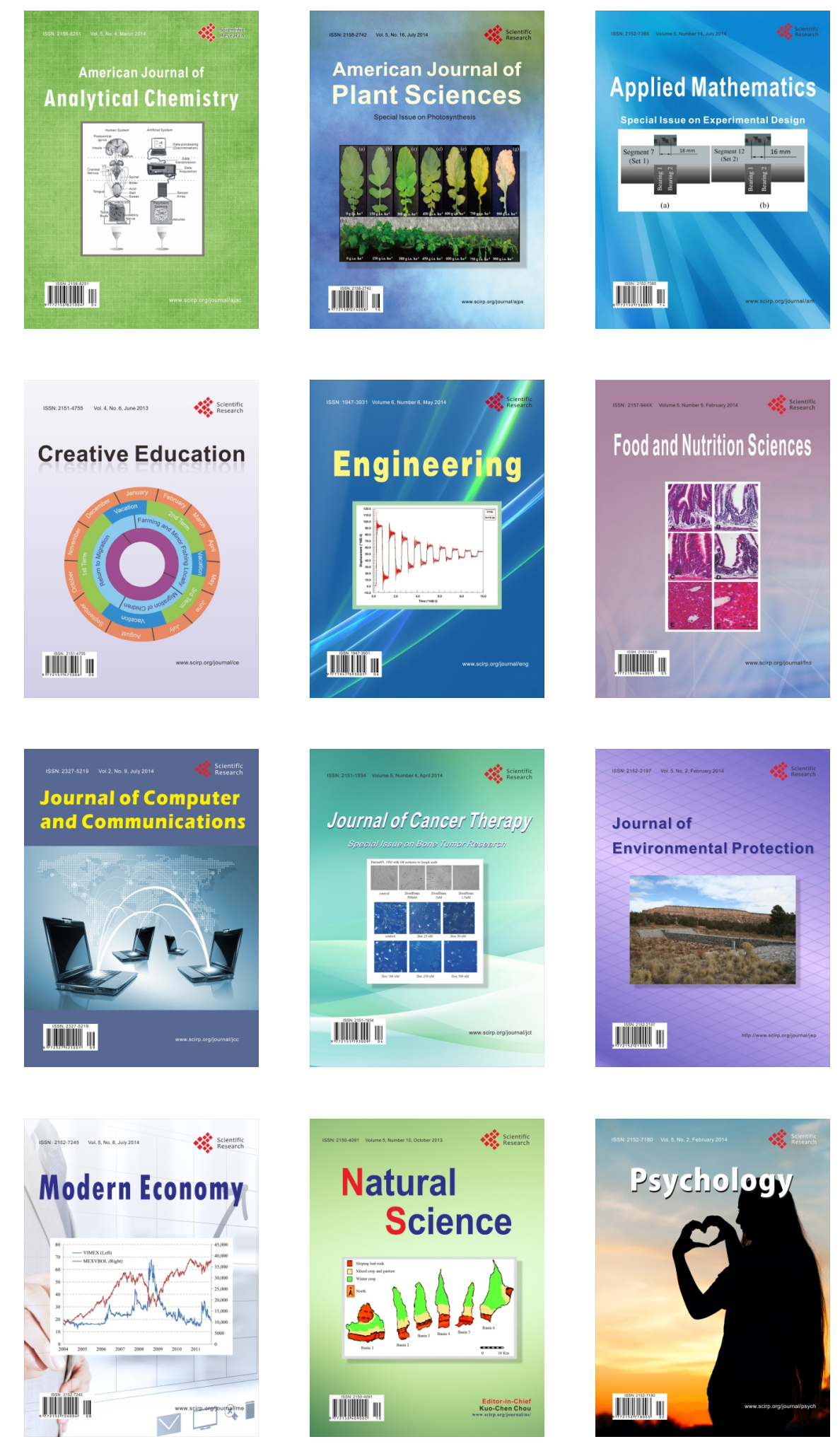